\title{
Experiencing Authenticity at Alvar Aalto's Experimental House
}

\author{
Anne-Maija Malmisalo-Lensu
}

\begin{abstract}
Experiences of authenticity are studied at Alvar Aalto's Experimental House - today a modern house museum - which has gone through renovations and changes. Visitors were interviewed to find out how they feel about the authenticity of the place, if the changes affect their experience of authenticity, and if they share the same opinions. A review of the literature on the concept of authenticity is carried out and its implications for museum contexts is considered, and then the research questions are answered by analysing 30 interviews of visitors to the Experimental House.
\end{abstract}

Keywords: authenticity, authentic experience, visitor experience, museum experience, modern house museum, architect's house, architectural tourism, Alvar Aalto.

This feels quite private, and that's what it is. [...] And it feels like they might still be alive somehow. They might just walk in and do some stuff, and, you know, have a break [...]. So, that's what's nice. [...] Obviously I would love to sit [...] and have a coffee. That would be nice. But I'd like that place to myself. So it's not very practical, I think. And because obviously [...] you can never experience that loneliness or moodiness on the tour. Thomas, 45, architect from the British Isles. ${ }^{1}$

Every person visiting a museum has his or her own subjective experience of authenticity and opinions about it. Thomas attended a guided tour at the Experimental House, which is the former summer house of the architect couple Alvar (1898-1976) and Elissa Aalto (1922-94), built on Muuratsalo Island in Central Finland in 1952-53. Thomas walked with his family and ten other people along a narrow path in a forest to see a boat, a sauna, and finally the house. At every stop, the guide explained the architecture, and told a little about the life of the former owners.

The house, rising on a rocky shore of Lake Päijänne, is a unique white building with a courtyard covered with experimental red brick panels, a wooden wing built on diagonal beams, and a butterfly roof with surfaces sloping down from opposing edges. Inside the house, there is a combined living room and studio with a mezzanine, a kitchen, a bathroom and several bedrooms. Aalto himself called the house experimental. His aim was to test the effects of different methods of jointing bricks from both 
Anne-Maija Malmisalo-Lensu

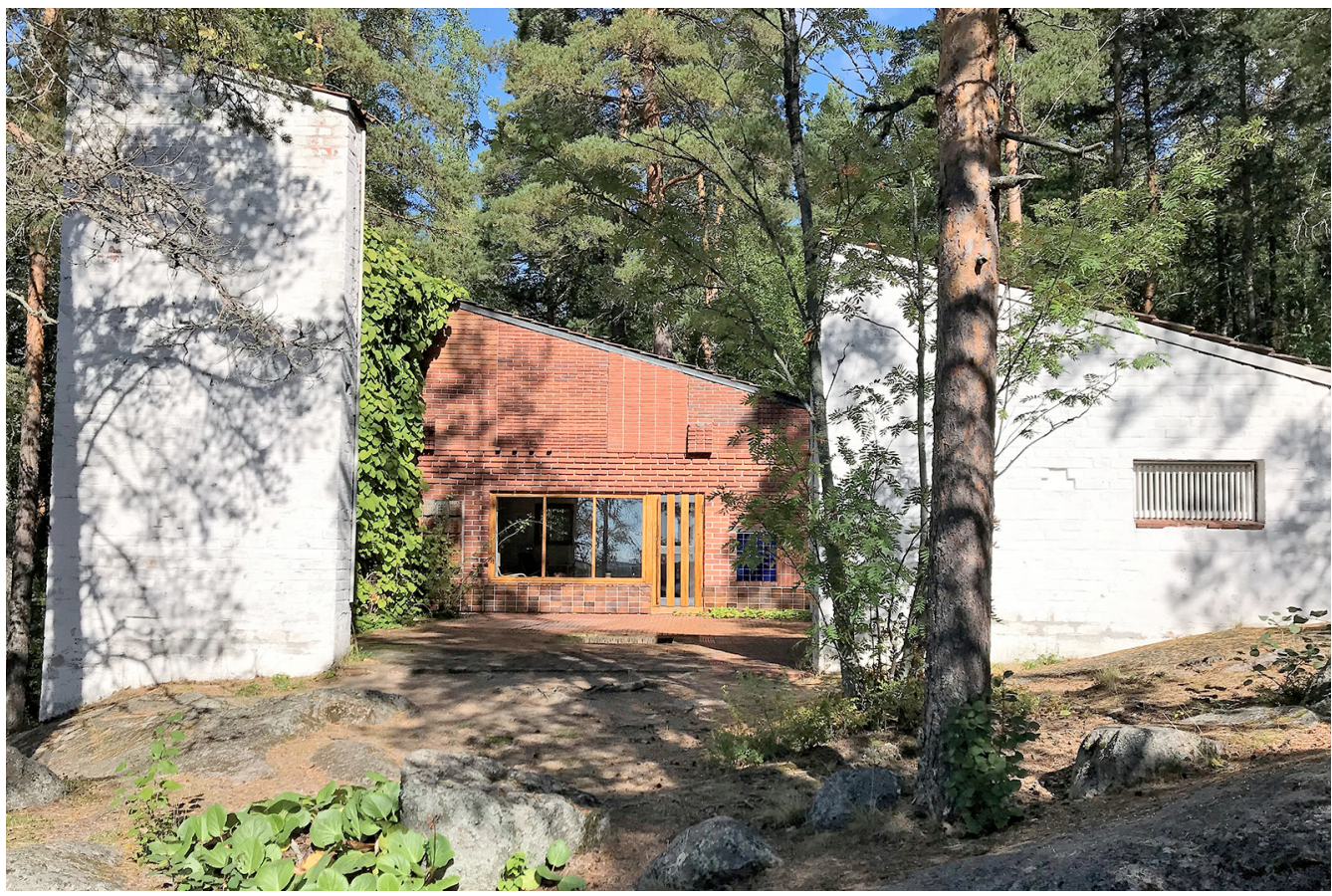

Fig. 1. The Experimental House was a summer house of architects Alvar and Elissa Aalto. The courtyard walls are covered with different brick and tile fields to test aesthetic and practical standpoints. Photo: author.

the aesthetic and practical standpoints, and to try out some technical solutions with wooden structures. The house is one of the main destinations for architectural tourists such as Thomas who are interested in Alvar Aalto.

For Thomas the Experimental House seemed very authentic: a house still functioning in its original use as a summer house, as well as performing the function of a museum, yet still appearing to be in its original state, though with an inevitable sense of staged authenticity because of the presence of the guide and the other visitors. He dreamt of spending time alone in the house - a dream that alas cannot feasibly become a reality.

House museums like the Experimental House provide at their best an authentic experience. What constitutes authentic experience has been considered in research carried out within museum and tourism studies since the 1960s. A more recent study by Goulding (2000) explored the nature of authenticity as defined and constructed by visitors to three heritage sites: a living museum village, a ruin and a traditional historic and art museum. The study explained authentic experiences in the light of three identified types: the "existential", the "aesthetic" and the "social" visitor. For the existentialists, positive experiences were more important than historical facts. For the aesthetic visitors the experience was nostalgic, with historical accuracy an integral part of the experience, while the social visitors emphasized the social and entertainment 
aspects of experiences while the authenticity of the artefacts was not emphasized.

Later Gregory \& Witcomb (2007) studied the role of affect in generating historical understanding at house museums. According to them, the furnishing had a significant role. Houses furnished to generate a romantic vision and create nostalgia were meaningful to people who had their own memories from the time the houses were set in, but the houses with minimal furnishing and with more empty space affected younger people. According to Hede \& Thyne's (2010) research in the house museum of author Janet Frame in New Zealand, inauthentic artefacts did not prevent visitors from experiencing authenticity. The visitors were able to feel existential authenticity in particular. Also Simonsson (2014:82$83,108,168,193)$ found that an authentic experience is possible even though there may have been changes in the spaces or objects. Even restoration can help visitors have a more authentic experience.

Some renovation work was carried out after the building of the Experimental House was finished. For example in 1995-98, just before the house was opened to the public by the Alvar Aalto Museum, the building went through a major renovation in which among other site works the floors were partly rebuilt, the walls painted, and the roofing felt renewed. ${ }^{2}$ The furniture was partly replaced with copies or new pieces. Because of all the changes in materials and functions of the house, I became interested in how the visitors experience authenticity in a modern house that is an architecturally significant house museum yet that has undergone such changes. The earlier studies had been carried out in different kinds of historical environments and old buildings, but not in a house that is a work of art itself, an architecturally interesting destination. How do the visitors experience a house like this and does authenticity matter?

This paper aims to investigate the concept of authenticity: how it can be understood and what types of authenticity are articulated by visitors. It also focuses on how physical alterations to the Experimental House affect this articulation. The research questions are: How do the visitors articulate their own experiences of authenticity in the Experimental House? Do their observations of alterations affect their experience of authenticity? Do the visitors have the same or similar opinions about authenticity, or are there different views? In this qualitative study thirty visitors were interviewed, and a content analysis was made to discover the visitors' opinions on their experiences of authenticity. First, an overview is presented on the concept of authenticity.

\section{Authenticity in the Context of MUSEUMS AND TOURISM}

The concept of authenticity has been discussed in several disciplines. In museum-linked studies authenticity is discussed both in the context of the conservation and restoration of objects, and in the context of visitor experiences. As Wang (1999:351) has pointed out, the issue can be divided into two separate subjects: experiences and toured objects, which include also heritage monuments and sites. In tourism studies this kind of authenticity is often called "museum-linked authenticity" with a reference to Wang or to Lionel Trilling's book Sincerity and Authenticity (1972). ${ }^{3}$ According to Trilling the provenance for the word is the museum

[...] where persons expert in such matters test whether objects of art are what they appear to be or are claimed to be, and therefore worth the price that is asked for them 
- or, if this has already been paid, worth the admiration they are being given (Trilling 1972:93).

This may have been partly true in some cases in the past, but this kind of definition does not satisfy museum professionals of the twenty-first century. In museums, the monetary value of an object is a secondary value. Museums collect objects because of the historical information they communicate or because of their possible use in scientific research, in exhibitions or in other museum work (Heinonen \& Lahti 2001).

Authenticity has a crucial role in the conservation of museum objects and heritage buildings. ICOMOS has taken a big role in defining authenticity in this field. For example the Venice Charter (1964, Internet source 1), gave instructions to let "the full richness of [objects'] authenticity" be shown. Copies have become accepted if it is important to protect the originals. (Jokilehto 1999:296) The Council of Europe has given recommendations on the protection of the twentieth century's architectural heritage (1991, Internet source 2) and of the interiors of buildings, including immovable and movable property (1998, Internet source 3) to maintain authenticity. According to the UNESCO World Heritage List Operational Guidelines (1996, Internet source 4) authenticity must be found in the design, material, workmanship and setting of the site (Jokilehto 1999:298). Later the number of attributes has increased, to include for example "spirit and feeling" (2017, Internet source 5).

During the twentieth century in discussions of authenticity "experience" was often mentioned. One of the prominent figures in the debate was the philosopher Walter Benjamin (1892-1940) whose ideas are still often referred to in various disciplines (Rickly-Boyd 2012). Friedlander (2012:148) has underlined that Benjamin "speaks of authenticity from the point of view of the experience rather than the production of the work". Physical changes that occur in the object over time, or different owners of the object, do not reduce the authenticity. More important is the "aura" of the object, a characteristic of all authentic objects (Benjamin 1989/1936:142, 144). As Rickly-Boyd (2012: 270) depicted, 'aura' is an experience, an engagement, defined [by Benjamin] as a 'strange tissue of space and time: the unique apparition of a distance, however near it may be." Later many researchers, for example art historians Ernst van de Wetering (1996/1989 cited in Saaze 2013:50) and Nicole Ex (1993:94 cited in Saaze 2013) also understood "aura" as the experience of authenticity and as a quality of an object.

In the context of museums, Vilkuna (1997: 57) has written about "object-energy" as a quality of a museum object. According to Vilkuna it is "the evidence that objects include, and are transmitting". The term refers also to an experience. Object-energy is an aura-like subjective feeling a person experiences from a museum object. In this respect authenticity includes always an experience. Therefore, it is presumed that the visitors - despite the changes including at the Experimental House - may have gained an experience caused by the aura or the object-energy of the house.

In tourism studies, authenticity acquired a central part after McCannell (1973, 1976) wrote about the concept in sociological studies of tourist motivations and experiences (Wang 1999:349). MacCannell (1973:590) brought Goffman's (1959) theory about the theatricality of everyday life into the context of tourism. Goffman's structural division of social establishment made distinctions between front stage - where the audience (tourists) and performers (hosts or staff persons) appear and back stage - which is for the performers 


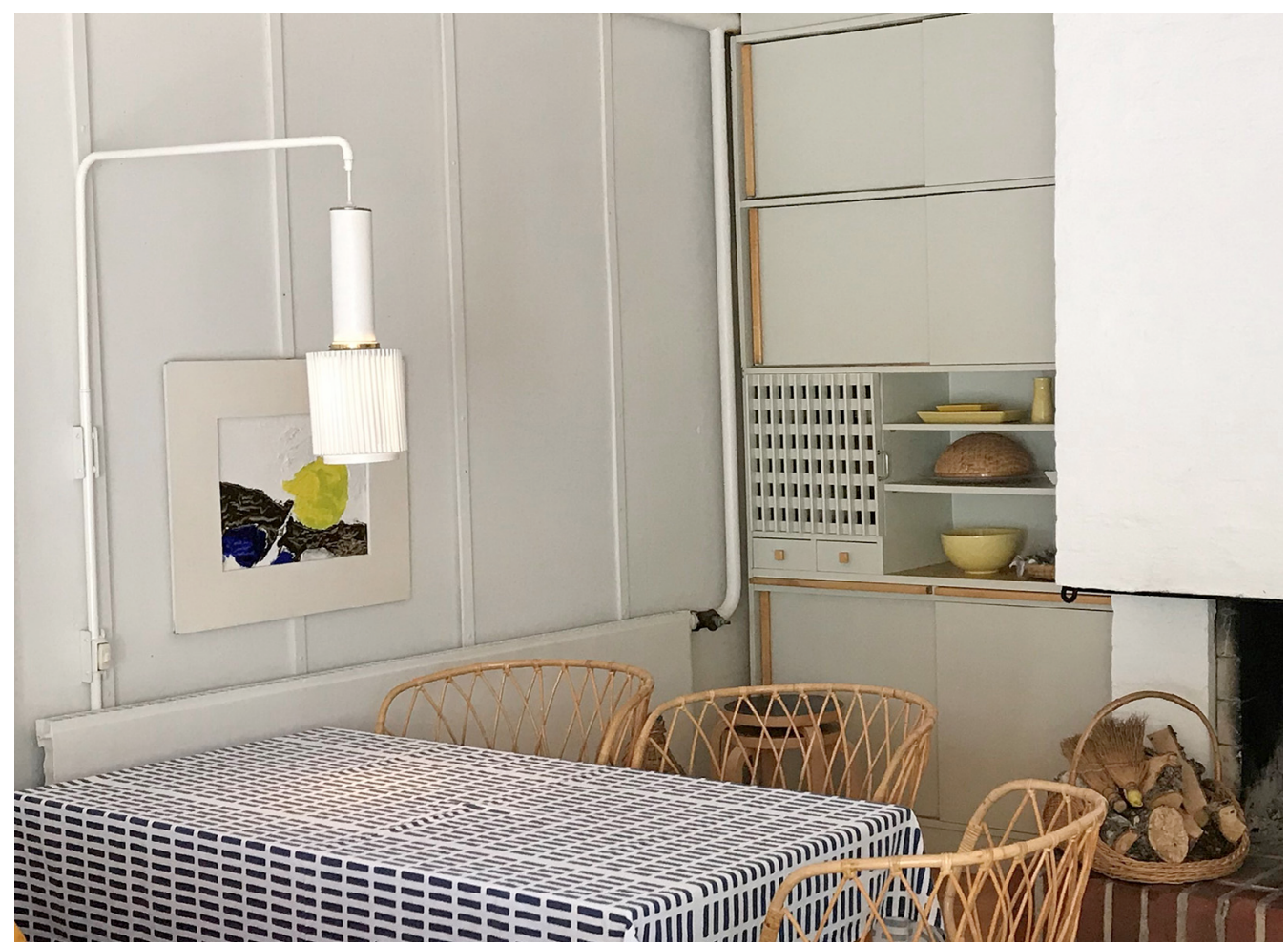

Fig. 2. The living room with the dining area is on the front-stage, but it is also still used by the Aalto family. To protect the furniture, visitors are not allowed to sit on the chairs. Photo: author.

only. According to MacCannell (1973:592, 595) some tourists are motivated to experience the back regions, "life as it is really lived", even though they fail to enter there. MacCannell (1973:593) did add however that for other tourists back regions are not important.

Numerous researchers (see Wang 1999:349) have since dealt with authenticity in the context of tourism. Different views and multiple meanings of authenticity appeared (Cohen \& Cohen 2012:2179). Finally, Ning Wang (1999) wrote a summary of the earlier discussions. Wang (1999:350) stated that authenticity is a relevant motivation especially for ethnic, history, and culture tourism. He wrote about four types of authenticity: objective, constructive/symbolic, postmodern and existential/ subjective. These authenticity types are explained later in a section about visitor experiences on authenticity. Authenticity of tourism experiences still interests researchers.

\section{MATERIAL AND Method}

To find out about visitor experiences concerning the authenticity of the Experimental House, thirty visitors from twelve countries were interviewed using a semi-structured interview 


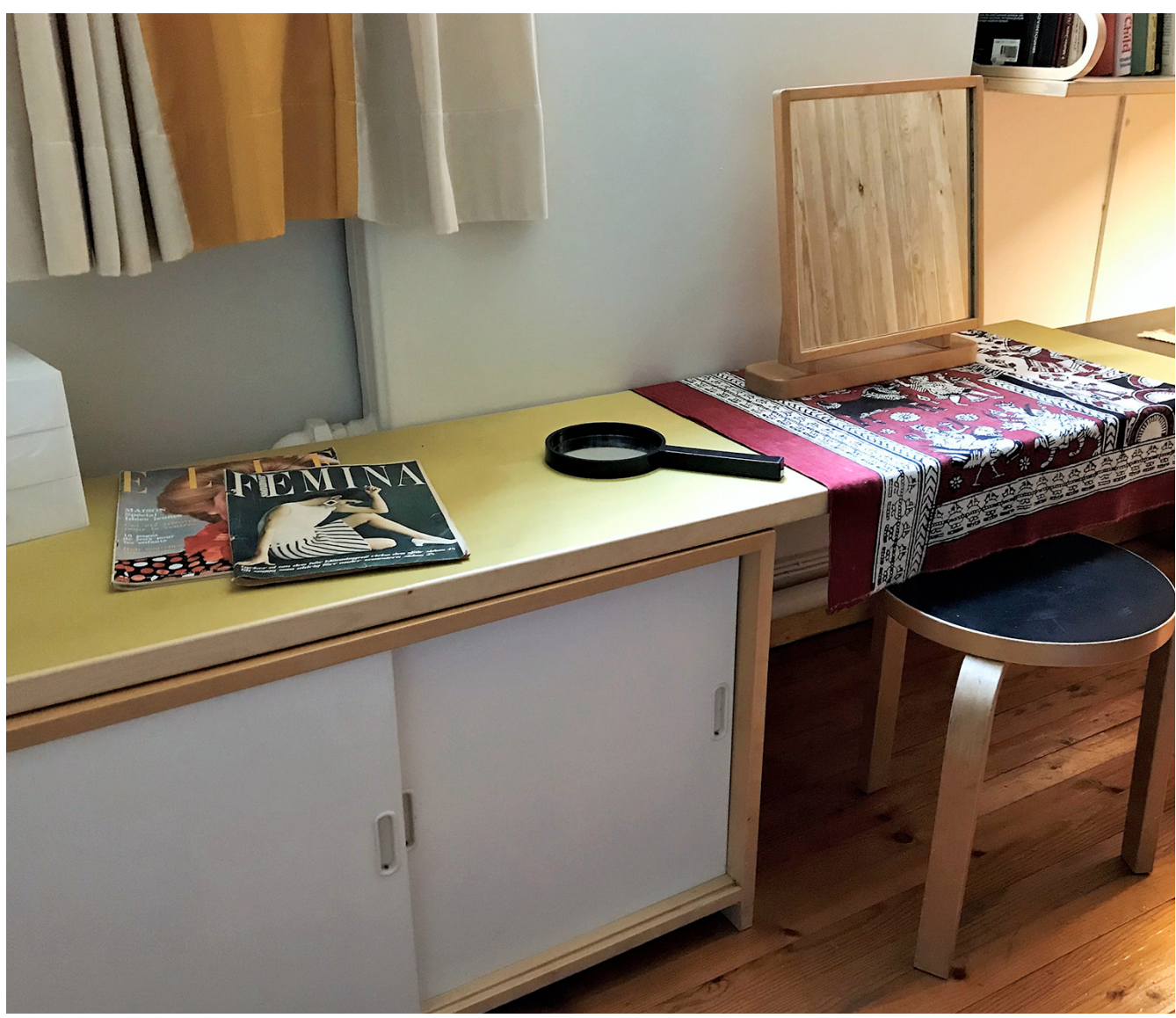

Fig. 3. Some magazines and objects have been placed by the museum staff on Elissa Aalto's bedroom table. Photo: author.

in a qualitative research. Thus the results will not be statistically significant but indicative. The objective is not to generalize the results but to get answers for other, similar cases. The interest is in individual visitors (Internet source 6).

The respondents were selected using demographic indicators (age, gender), geographic criteria (homeland, home continent) and education-related classifications (professional, non-professional). "Professional" is a person working or studying in the architectural, design or museum field. The 30 informants are a small sample from a larger research, and therefore the demographic variables are mainly ignored in the results of this study because the sample is too small to reveal significant differences. The interviews were carried out during the summers of 2017 and 2018 after some guided tours at the Experimental House. 
The Experimental House and the site themselves have an important role in the research. The house is a museum, but part of the house, the so-called guest wing, is a more private, back-stage area that is still in the use of Alvar Aalto's descendants, and largely not used by the museum. Because the house is quite small, the Aalto family uses the "museum spaces" - the front regions - to some extent. There is an agreement between the museum and the family about what may be used and when. The bedrooms in the main part of the building and the kitchen belong to the tour, but they can be viewed only from the corridor.

Because of the private use, the fragile environment, and the need to preserve the house, the Alvar Aalto Museum has decided to keep the area and the house open to only a certain number of visitors, with access to the area being allowed only with a guide. The environment is an essential part of the tour. The Aaltos spent a lot of time outdoors, and the relationship between architecture and nature was very important to them. On the site there are also a motor boat, a smoke sauna, and a woodshed - all designed by Alvar Aalto. To make the tour of the house more readily accessible a new path in the area has been made.

The presence of a guide and a group of visitors together with the changes and alterations on the premises may affect the experience of authenticity. Both the international principles for conservation defined by ICOMOS and the Council of Europe - including the protection of the authenticity of the building - and the different visitor experiences of authenticity as defined in tourism research, meet at the Experimental House. As a framework for the experiences, I am using the concepts depicted by Wang (1999) and MacCannell (1973): the objective, constructive, postmodern and existential authenticity, and the front stage 29 back stage division.

The informants were asked direct questions concerning authenticity, but some of their comments dealing with authenticity were also found in their responses to other questions, and those answers were taken into account as well. They were not asked directly to define what they understood by the word authenticity, the definition came out in their answers.

The hypothesis was that visitors have different kinds of views and experiences of authenticity, as has been presented earlier. The assumption is that in cultural heritage sites, like the Experimental House, the experiences are mainly objective-related, but also other kinds of experiences of authenticity may appear, especially existential authenticity for example described in the research by Goulding (2000) and Hede \& Thyne's (2010).

\section{VISITOR EXPERIENCES ON AUTHENTICITY AT THE EXPERIMENTAL House}

Front stage - back stage division

According to MacCannell (1973:589ff.) tourists attempt to go to the back regions because these regions are associated with more authentic experiences and intimate relations. Back regions wake up curiosity and a belief that there would be something important or interesting to see. Often tourist settings deliberately give an impression that tourists are in a back region when they are not, as happens partly also at the Experimental House.

The understanding of staged authenticity appeared in the answers of 13 persons and convey their understanding of being in a museum. Four persons mentioned the present day use of the summer house as a factor that affects the authenticity, and four persons (two 
of them the same ones as earlier) mentioned the feeling of visiting a private house. The other persons saw the private use positively, but Jan (70, non-professional, Central Europe) saw it negatively. For him an optimal visit would have been to a house that is not a museum, and to see the back regions. According to him (note that most of the interviewees were not native English speakers; the quotes are their exact words unless they have been translated from Finnish or Swedish):

The problem is [...] you'd like to see it [has] been used. [But] if it's [actually being] used you cannot go there, because you would unsettle the users. So, it's always kind of museum like. Yes? And that's limitation, [...] as there is no other way.

The feeling of visiting someone or the Aaltos was mentioned by four architects: Mikko (30, Finland), Laura (30, architect student, Finland), Thomas (45, the British Isles) and Lena (65, North Europe). In Mikko's words:

Compared to most architectural sights I visit, this is more intimate and homely. Here it feels like coming into someone's home. [...] It feels like Alvari has just nipped out to go for some groceries, and then we have just come to his cottage.

When the visitors were asked about improving services at the site, Julia (20, architect student, Central Europe), Juan (70, architect, Southern Europe) and Stefan (55, non-professional, Central Europe) were afraid changes would have negative effects. Many visitors would have wanted better signs to the parking place and the gate of the area, but Juan and Stefan disagreed.

Because the staged authenticity was recognized, Clara (35, non-professional, South America) and Thomas (45, architect, the
British Isles) were hoping the museum would raise the level of authenticity by creating back stage experiences by letting visitors spend time at the house in more authentic circumstances. Clara had discussed the issue in general a day before:

[...] to live an experience [as if] you were really living in the house and not only watching it, something like piece of art. [...] That you could see and have a tea and talk, and maybe [as if] you [were] liv[ing] there, you know, or... [as if] you were visit[ing] the owners of the house [...].

Clara also thought a visit without a guide would feel more authentic, too and Thomas expressed the same idea. In addition, two persons added their observations concerning the front stage. Juho (15, Finland) had noticed staged arrangements in the bedrooms like magazines placed on a table and clothes hanging in the wardrobe, and Riitta (65, non-professional, Finland) thought the whole tour was "nicely constructed".

\section{Objective authenticity}

Objective authenticity means that "the authentic experience is caused by the recognition of the toured objects as authentic" (Wang 1999:351). Wang (1999:350f) made a distinction between authentic experience (a subjective feeling) and toured objects (a quality of the object). For example, the tourists may think they are having an authentic experience that is in fact inauthentic because the toured objects are not genuine. This is what MacCannell called "staged authenticity".

Cohen (2007:77) has stated that the marking of a site, sight or object for touristic purposes reduces the objective authenticity. Cohen cited an old church as an example: "marked as an attraction, but still in use, [it] can be said to be more 'objectively authentic' than one 
which was turned into a museum for tourists". Semioticians Percy (1975) and Culler (1981) also pondered the question of marking. They thought that a site needs to be certified as authentic with markers of authenticity to be experienced as authentic, even though a site marked as authentic is not authentic in the sense of unspoiled. Therein lies a paradox.

According to Cohen's (2007:77) definition the amount of (the objective) authenticity of the Experimental House has decreased because it's marked as an attraction, but because the Aalto family still uses the house, it is more authentic than a house which has been turned over completely to use as a museum.

As expected, nearly all respondents in this research (27 out of 30) mentioned something about the objective authenticity. They were asked what they thought about the authenticity of the house, and if too many changes had been made. Seven persons thought that the house was very authentic. They had not noticed or at least they did not mentioned anything that would have affected its authenticity. As Tiina (35, non-professional, Finland) said:

If this [house] wasn't authentic, you would notice it. [...] If something here were fake, you would get a feeling that this is not contemporary, or wonder if this thing really was this way in Aalto's time. It would disturb you.

Most of the visitors mentioned something about changes. Sofia (15, Finland) said that she noticed something only when the guide told them about the renovations. Carlos (40, non-professional, Southern Europe), Maria (60, non-professional, Southern Europe), and Sirpa (55, non-professional, Finland) had also paid attention to some changes, but they didn't comment on them. Sirpa was more interested in original things and she mentioned she felt nostalgic when seeing (authentic) kitchen fittings from the 1950s. Jukka (65, architect, Finland) had paid attention to some changes, and for him the modern tap in the kitchen was disturbing. He suggested it could be changed to an older style. In addition two persons, Riitta (65, non-professional, Finland) and Stefan (55, non-professional, Central Europe) also paid attention to the surrounding nature and possible changes in the scenery.

Eight persons (half of them professionals and half non-professionals) mentioned that changes in a building are normal or necessary. One of them was Sanna (35, professional, Finland) who stated: "Are there any buildings without layers from different time periods? If a house has been for summer use for a long time, signs of that life must still be visible." Stefan (55, non-professional, Central Europe) pondered the question further in the spirit of the ICOMOS charters:

I think it's not possible - such a place like this - to keep it in an authentic state, because even the wood and bricks deteriorate [...] This is not a structure that will last for hundreds of years if it's not always being updated. So, I think the history of this building will continue and the important thing is to do it with intelligence and good thinking, and not to be afraid to be in charge of it.

\section{Constructive authenticity}

According to Wang $(1999: 351,356)$ constructivists are also in search of authenticity: "The toured objects [...] are experienced as authentic not because they are originals or reality, but because they are perceived as the signs or symbols of authenticity. [...] In this sense, what the tourist quests for is symbolic authenticity."

The experience of authenticity is a result of a social construction that might be affected by stereotypical images, or one's dreams, beliefs, or expectations. The authenticity is thus 


\section{Anne-Maija Malmisalo-Lensu}

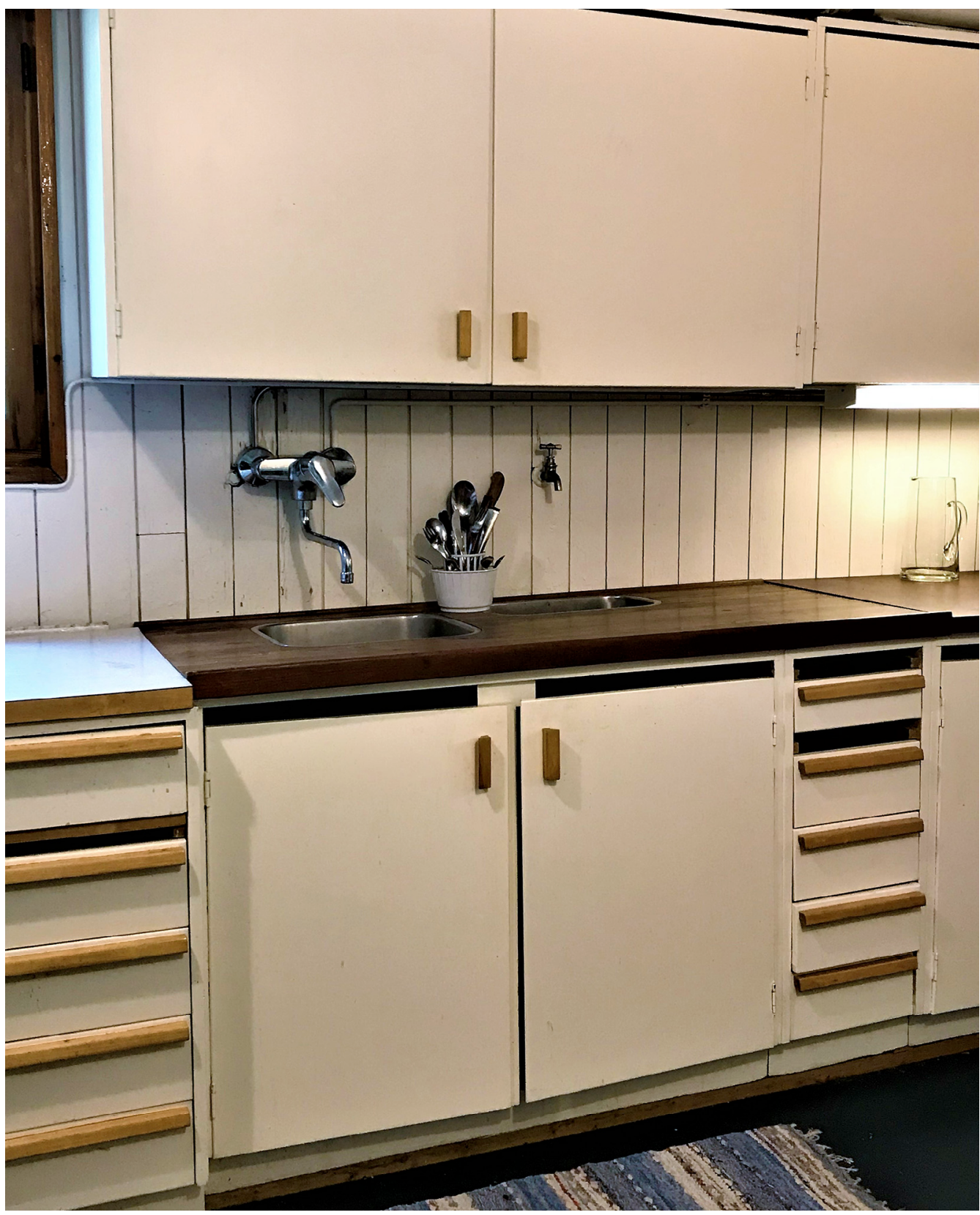

Fig. 4. The original kitchen fittings from the 1950's evoke nostalgic memories among visitors who have lived the era. The modern tap was criticized by an elderly architect. Photo: author. 
projected on to toured objects by tourists or tourism producers (Wang 1999:351f.). Also according to Cohen (2007:78) it is by their subjective practices that people construct "objective" authenticity of a sight, object or site. The decisions made by professionals are socially constructed as well. Because experiences are subjective, there are various versions of authenticities in the same objects.

In the interviews the opinions of Elena (30, architect, Southern Europe), and Emma (45, architect, the British Isles) were constructive. In spite of the changes she noticed, Elena said: "I think the spirit is the same. [...] I think it's authentic. It gives me the impression [of authenticity]." Also Emma had recognized changes: "It's obviously been kept well, but it's not $[. .$.$] you know, like treated too preciously,$ either. [...] It feels authentic, definitely. [...] I think it's authentic, yeah." For Elena and Emma the changes did not reduce the level of authenticity. That is consistent with Benjamin's (1989/1936) and Wang's (1999:355) thoughts.

\section{Postmodern authenticity}

In postmodern thinking the distinction between "representations" and "reality" is not clear (Urry 2006:77). For example according to McCrone et al. (1995:46) in the context of heritage the postmodernists think that "reality depends on how convincing the presentation is, how well the 'staged authenticity' works". The public may very well know the presentation is staged, but the authenticity is not important for them (Wang 1999:357).

Actually this - the unimportance of authenticity - is not a new phenomenon. For example during the nineteenth century copies of art were often on display at exhibitions and collection displays. Also, the first art dealers sold among the original objects sculpture copies made of plaster and marble, and copies of oil paintings. Museum authorities, like the Finnish Art Society, purchased cheaper copies instead of originals. The ideas that the art pieces were mediating were more important than their originality (Pettersson 2008:92f, 96, 112f, 129, 255f; Mårdh 2015:34)

For postmodernists what is important is the direct impact on oneself and experiencing pleasure - preferably informally (Urry 2006: $74,76)$. Instead of authentic experiences, the postmodernist prefers enjoyable moments (Wang 1999:357). Ritzer \& Liska (1997:107) have given an example of how most postmodern tourists would prefer a campfire on the lawn of the hotel, and not in the woods. They argue that many tourists are not looking for authenticity but inauthenticity. According to Urry (2006:92) a postmodern tourist is aware of inauthenticity:

[...] the post-tourist knows that he or she is a tourist and that tourism is a series of games with [...] no single, authentic tourist experience. [...] The post-tourist knows that he [sic] is: 'not a time-traveller when he goes somewhere historic; [...] not an invisible observer when he visits a native compound. Resolutely 'realistic', he cannot evade his condition of outsider.' (Feifer 1985:270f cited in Urry 2006:91).

Postmodern authenticity was also present in the interviews at the Experimental House. Five persons mentioned that they noticed changes in the house, but the changes were not disturbing. For example Stefan (55, nonprofessional, Central Europe) stated: "I think the building is important, and the atmosphere and the quality of the building, and not the original state of anything." The postmodern view is in the line with Simonsson's (2014) research.

According to Wang (1999:358) objective authenticity (the authenticity of the original) 
is in a crisis with both constructivists and postmodernists. Constructivists have altered the meaning of authenticity, and postmodernists ignore it. Nevertheless, the postmodernist view paved the way for the definition of existential authenticity.

\section{Existential authenticity}

Existential authenticity means personal or interpersonal feelings generated by tourist activities. When people gain that kind of experience, they feel themselves - in Wang's (1999:351ff) words - "more authentic and more freely self-expressed than in everyday life, not because they find the toured objects are authentic but simply because they are engaging in nonordinary activities, free from the constraints of the daily." For example Heuermann \& Chhabra (2014) have later included all kinds of individual experiences, emotions or spiritual connections - both positive and negative - to be labeled as existentially authentic.

The conception of existential authenticity came to tourism research largely in the 1990 s, but it has a long history starting from Kierkegaard through Nietzsche, Heidegger, Sartre, and Camus. The conception has dealt with "a special state of Being in which one is true to oneself”. According to Heidegger (1962 cited in Wang 1999) to look for the meaning of Being means searching the meaning of authenticity (Wang 1999:358). According to Reisinger and Steiner (2006:307) the existential tourism experience comprises in practice "a desire to make up one's own mind about what is going on during the tourist experience, [...] to be uninterested in a tour guide's explanation, [...] to get off the beaten track, away from crowds, away from the popular tourism spots."

According to Rickly-Boyd many researchers mix different authenticity categories: "There is a strong interaction between object, site, and experience; they are not mutually exclusive." Rickly-Boyd (2012:277) connected the Benjaminian aura of objective authenticity to an "authenticated tourist experience" - i.e. the existential experience. She stated that even though Benjamin was not an existentialist his concept of aura could be used to describe an experience between person and object/site. Thus, the subjective experiences - feelings - gained by objects can also be considered as existential authenticity.

Existential, intrapersonal feelings appeared among the comments of three architect visitors. Elena (30, Southern Europe) took part in the tour with her husband. After the guide finished there was some time to explore the house and the area independently. Elena thought the tour was too crowded, so after the tour they went back to go round once more on their own. She said: "We had another tour on our own. And it was really beautiful, a very close... a closer relationship with what you can see." She also said she visits architectural sites "to enjoy the experience, to feel the places".

Julia (20, architect student, Central Europe) said the place aroused strong feelings. She was "thrilled" - as she put it - to visit the house: "I would have cried [my eyes out] if I hadn't been able to come here." When she was asked about the authenticity, she started to tell how she feels: "I feel like... Maybe the first thing that hit me, was the smell of the house, [...] it smells like a home. [...] You feel that you're in an old house and though, yes, it looks used, that's how it makes the house beautiful. ... There's the spirit!"

Akihiro (35, architect, Japan) made a comment on existential authenticity, but he said he would have liked to have had stronger feelings: "The experience itself is great. Maybe there are too many people visiting at the same 
time, making hard to understand the original feeling of the building."

For 28 visitors the visit to the house was positive. A total of 21 visitors expressed feelings which can be related to an aura or objectenergy experience. Comments like "Lovely, calm place," (Daniel 35, architect, Central Europe), "When the main house [...] rose up in front of me it was a bit of a wow moment," (Mikko 30, architect, Finland), and "I could feel the sense of history," (Sofia 15, Finland), were expressed. For example for Riitta (65, non-professional, Finland) the visit was very significant: "This [place] is going to stay in a certain way in my mind, in my thoughts. That's how I feel."

\section{Conclusions AND Discussion}

The research was carried out at the Experimental House, which is a house museum with significant architecture. Earlier studies that have dealt with authentic experiences in museums have been implemented in more traditional places where often a historical person or a display, not the architecture of the building, have been the focus. The Experimental House is visited mainly by architects and students of architecture, but also by persons who are interested widely in culture and museums. That makes it possible to take into account opinions from both of those visitor categories.

To summarise, authenticity was understood in several ways. All the authenticity categories that were mentioned earlier were present in the interviews, but mostly the visitors discussed objective and postmodern authenticity. Subjective feelings that arose from the site that also belong to existential authenticity according to Rickly-Boyd (2012) were widely present.
There were not significant differences between the answers of the professionals and the non-professionals, but the constructivist and the existential viewpoints were mentioned only by architects.

The private use of the house by Aalto's descendants - a back stage factor - increase the authenticity. Many visitors valued the private, original nature of the place and they wanted to keep it as it is and not to become more like a tourist attraction - even if it already is one. Some visitors were afraid that possible changes would affect the authenticity in a negative way, and that better signs outside the area would reduce authenticity. Two visitors even wished they might have been able to have a private (back stage) visit to be able to feel the house more authentically. These results are in line with MacCannell's (1973) observations that tourists are seeking authenticity and sometimes specifically in back stage regions.

Most of the visitors thought the alterations did not disturb the objective authenticity of the house but were normal or necessary. Only two persons did think the changes were a little disturbing. Constructive authenticity appeared only in two answers, and postmodern notions or views were mentioned by five visitors. Existential, intrapersonal feelings were experienced by two persons, and one person mentioned the lack of those feelings. In addition, feelings concerning the aura or object-energy of the house or the site, which can also be interpreted as existential authenticity, were expressed by 21 interviewees. That is to say, most of the visitors felt different kinds of intrapersonal, mainly positive feelings.

The results were analyzed from material that was collected for a larger research concerning the motivations, expectations, and experiences of visitors in three modern house museums. Because the questions were not designed 
specifically for this study, many answers were somewhat superficial, making the analysis difficult. In a qualitative research the results are always an interpretation by the researcher.

The findings of this study show that there are no significant differences in relation to earlier studies in this field of research: visitors at an architectural site like the Experimental House have similar kinds of experiences of authenticity to visitors at other museum and heritage sites. The studies support each other. Research should be carried out with a larger sample of visitors to find any potential differences.

It has been important to examine the visitor experience of authenticity at Experimental House to find out what visitors value. The knowledge helps the museum to offer better experiences. The Experimental House is an example of an architectural heritage site and modern house museum such as may be found around the world. The results can be applied to other house museums.

Authenticity is "a pleasure factor", as Tiina (35, Finland) stated. To generate (positive, in some cases also negative) feelings is important for the visitor experience, and that is what museums usually aim at. In museum exhibitions, staging is used as a means of illustration, and it seems that in house museums staging is accepted if it is realized inconspicuously. The pleasure factor decreases if staging becomes too conspicuous.

The same happens if renovations are carried out that create unsuitable details. It is important to keep a balance between authenticity and staging, and between the original and the changes. If the visitors are not aware of the changes in relation to staging or renovation, their experience might feel more authentic. However, more important than original and genuine details is the atmosphere of the building and the feelings the visitors have. Objective authenticity matters, but as McCrone et al. (1995:46) have stated concerning the postmodern view on authenticity, the presentation needs to be convincing - the staging needs to work. As Simonsson (2014:196-197) has stated, experienced authenticity is based on the place's "sacredness and reclusiveness rather than on any historic qualities". These viewpoints were borne out also in this research. House museums worldwide have pondered the question of how to renovate and furnish a house museum. It would need more research to find out what kinds of changes visitors accept and what kinds of staging they find convincing.

The visitors' accounts indicate that iconic houses interest visitors. People want to experience the houses, and many have an urge to share in the aura generated by the authentic place and architect and the life lived there. House museums are facilitators in providing authentic experiences, but the quality of the experience depends also on the visitor. The museum administrators have a major responsibility to understand the importance of authenticity and staging. Authenticity must be taken into account to be able to offer a satisfactory and emotional visit. In this study, it was suggested that keeping the place "untouched" (i.e. with a convincing presentation and inconspicuous changes), having a smaller visitor group size, and the possibility to experience the house more privately, are aspects that would give visitors a better chance of experiencing the authenticity and aura of the house. Authenticity remains important for many visitors. 


\section{Notes}

1. To protect the anonymity of the interviewees their actual names are changed, and their ages are rounded up or down to the nearest 5 or 10 , so that for example a respondent who is 34 is given as 35 , and one who is 38 is given as being 40 .

2. In 1994 Elissa Aalto in her Will bequeathed the house to the Alvar Aalto Museum. A few years later the museum opened the house to the public, and it has arranged guided tours there every summer since 1997 . The Will also provide for the summer house to continue to be used by members of the family. (Alvar Aalto -museo, Vuosi- ja toimintakertomukset 1995-2018; Elissa Aalto's last will 1994.)

3. For example Wang 1999, Reisinger \& Steiner 2006, Andriotis 2011, Rickly-Boyd 2012, Zerva 2015, and Amey 2018. Wang (1999) refers to Trilling, and many writers refer to Wang.

\section{REFERENCES}

\section{Unpublished Sources}

Alvar Aalto -museo 1995-2018. Vuosi- ja toimintakertomukset. (Annual reports of the Alvar Aalto Museum from 1995 to 2018.)

Elissa Aalto's last Will 1994. Alvar Aalto Museum's archive.

Interviews made at the Experimental House in 20172018 by the author.

\section{Internet Sources}

1. "International Charter for the Conservation and Restoration of Monuments and Sites (The Venice Charter 1964)." https://www.icomos.org/charters/ venice_e.pdf (accessed 19 June 2019)

2. Council of Europe 1991. "Recommendation on the Protection of the Twentieth Century Architectural Heritage N0 R (1991) 13." https:// www.culturanorte.pt/fotos/editor2/1991 recomendacao_no_r_91_13_sobre_a_protecao_ do_patrimonio_arquitetonico_do_seculo_xx-
2019)

3. Council of Europe 1998. "Recommendation No. R (98) 4 on Measures to Promote the Integrated Conservation of Historic Complexes Composed of Immoveable and Moveable Property." http:// www.patrimonio-santarem.pt/imagens/3/ Recommendation_on_Measures_to_Promote_ the_Integrated_Conservation_of_Historic_ Complexes_Composed_of_Immovable_and Moveable_Property_1998_.pdf (accessed 26 August 2019)

4. UNESCO 1996. "Operational Guidelines for the Implementation of the World Heritage Convention." https://whc.unesco.org/archive/ opguide96.pdf (accessed 26 August 2019)

5. UNESCO 2017. “Operational Guidelines for the Implementation of the World Heritage Convention." https://whc.unesco.org/en/ guidelines/ (accessed 26 August 2019)

6. Saaranen-Kauppinen, Anita \& Anna Puusniekka 2006. KvaliMOTV - Menetelmäopetuksen tietovaranto. Tampere: Yhteiskuntatieteellinen tietoarkisto. https://www.fsd.uta.fi/ menetelmaopetus/ (accessed 23 August 2019)

\section{LITERATURE}

Amey, Evgenia 2018. “The Search for the 'Authentic' in the Context of Narrative-Inspired Travel." Nalans 6:10, 1-16.

Andriotis, Konstantinos 2011. “Genres of Heritage Authenticity. Denotations from a Pilgrimage Landscape." Annals of Tourism Research 38:4, 1613-1633.

Benjamin, Walter 1989/1936. “Taideteos teknisen uusinnettavuutensa aikakaudella." In Markku Koski, Keijo Rahkonen \& Esa Sironen (eds.). Messiaanisen sirpaleita. Kirjoituksia kielestä, historiasta ja pelastuksesta. [Helsinki]: Kansan sivistystyön liitto, 139-173. 
Cohen, Erik 2007. "'Authenticity' in Tourism Studies: Aprés la Lutte." Tourism Recreation Research 32:2, 75-82.

Cohen, Erik \& Scott A. Cohen 2012. "Current Sociological Theories and Issues in Tourism." Annals of Tourism Research 39:4, 2177-2202.

Culler, Jonathan 1981. "Semiotics of Tourism." The American Journal of Semiotics 1:1/2, 127-140.

Ex, Nicole 1993. Zo Goeld als Oud: De Achterkant van het Restaureren. Amsterdam: Amber.

Feifer, Maxine 1985. Going Places. The Ways of the Tourist from Imperial Rome to the Present Day. London: Macmillan.

Friedlander, Eli 2012. Walter Benjamin. A Philosophical Portrait. Cambridge, MA \& London: Harvard University Press.

Goffman, Eric 1959. The Presentation of Self in Everyday Life. Garden City, N.Y.: Doubleday.

Goulding, Christina 2000. "The Commodification of the Past, Postmodern Pastiche, and the Search for Authentic Experiences at Contemporary Heritage Attractions." European Journal of Marketing 34:7, 835-853.

Gregory, Kate \& Andrea Witcomb 2007. "Beyond Nostalgia. The Role of Affect in Generating Historical Understanding at Heritage Sites." In Simon J. Knell, Suzanne MacLeod \& Sheila Watson (eds.). Museum revolutions. How Museums Change and are Changed. London: Routledge, 263-275.

Hede, Anne-Marie \& Maree Thyne 2010. "A Journey to the Authentic: Museum Visitors and Their Negotiation of the Inauthentic." Journal of Marketing Management 26:7, 686-705.

Heidegger, Martin. 1962. Being and Time. Oxford: Blackwell.

Heinonen, Jouko \& Markku Lahti 2001. Museologian perusteet. [Helsinki]: Suomen museoliitto.

Heuermann, Katie \& Deepak Chhabra 2014. "The Darker Side of Dark Tourism: An Authenticity Perspective." Tourism Analysis 19:2, 213-225. Jokilehto, Jukka 1999. A History of Architectural
Conservation. Oxford \& Woburn, MA:

Butterworth-Heinemann.

MacCannell, Dean 1973. "Staged Authenticity: Arrangements of Social Space in Tourist Settings." American Journal of Sosiology 79:3, 589-603.

MacCannell, Dean 1976. The Tourist: A New Theory of the Leisure Class. New York: Schocken Books.

Mårdh, Hedvig 2015. "Re-entering the House. Scenographic and Artistic Interventions and Interactions in the Historic House Museum." Nordisk Museologi 1, 25-39.

McCrone, David, Angela Morris \& Richard Kiely 1995. Scotland - the Brand. The Making of Scottish Heritage. Edinburgh: Edinburgh University Press.

Percy, Walker 1975. The Message in the Bottle. New York: Farrar, Strauss and Giroux.

Pettersson, Susanna 2008. Suomen Taideyhdistyksestä Ateneumiin. Fredrik Cygnaeus, Carl Gustaf Estlander ja taidekokoelman roolit. Helsinki: SKS \& Valtion taidemuseo.

Reisinger, Yvette \& Carol J. Steiner 2006. "Reconceptualizing Object Authenticity." Annals of Tourism Research 33:1, 65-86.

Rickly-Boyd, Jillian M. 2012. "Authenticity \& Aura. A Benjaminian Approach to Tourism." Annals of Tourism Research 39:1, 269-289.

Ritzer, George \& Allan Liska 1997. “'McDisneyization’ and 'Post-Tourism': Complementary Perspectives on Contemporary Tourism." In Chris Rojek \& John Urry (eds.). Touring Cultures. Transformations of Travel and Theory. London: Routledge, 96-109.

Saaze, Vivian van 2013. Installation Art and the Museum. Presentation and Conservation of Changing Artworks. Amsterdam: Amsterdam University Press.

Simonsson, Märit 2014. Displaying Spaces. Spatial Design, Experience, and Authenticity in Museums. Umeå: Umeå Universitet.

Trilling, Lionel 1972. Sincerity and Authenticity. Cambridge, Mass.: Harvard University Press. 


\section{Experiencing Authenticity at Alvar Aalto's Experimental House}

Urry, John 2006. The Tourist Gaze. London: SAGE

Publications.

Vilkuna, Janne 1997. "Comments on Outi Peisa's

Paper Presented at the Seminar: Stories of Museums." Ethnologia Fennica 25:57-61.

Wang, Ning 1999. "Rethinking Authenticity in Tourism Experience." Annals of Tourism Research 26:2, 349-370.

Wetering, Ernst van de (1996/1989). “The Autonomy of Restoration: Ethical Considerations in Relation to Artistic Concepts." In Nicholas Price, Mansfield Kirby Talley \& Alessandra M. Vaccaro (eds.). Historical and Philosophical Issues in the Conservation of Cultural Heritage. Malibu: J. Paul Getty Trust, 193-199.
Zerva, Konstantina 2015. "Visiting Authenticity on Los Angeles Gang Tours: Tourists backstage." Tourism Management 46, 514-527.

Anne-Maija Malmisalo-Lensu MA, Ph.D. Candidate in Art History anne-maija.malmisalo-lensu@jyu.fi

Department of Music, Art and Culture Studies PO Box 35

FI-40014 University of Jyväskylä 